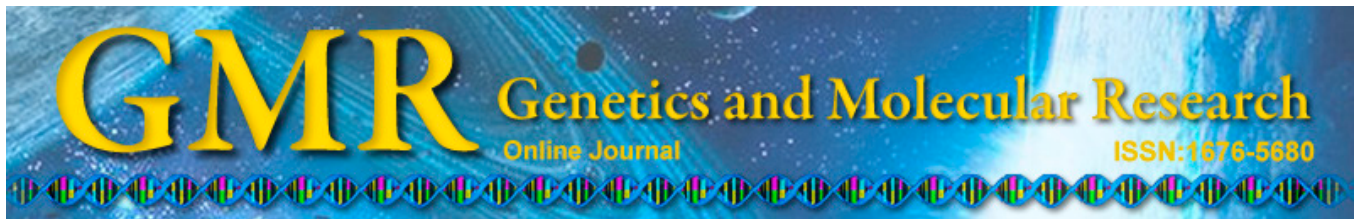

\title{
Identification of aac(2')-I Type b aminoglycoside- modifying enzyme genes in resistant Acinetobacter baumannii
}

\author{
T. Lin, C.G. Tang, Q.H. Li, J. Ji, H.Y. Ge, X.Y. Zhang and H.P. Sun
}

Department of Clinical Laboratory,

Huai'an First Hospital Affiliated of Nanjing Medical University, Huai'an, China

Corresponding author: C.G. Tang

E-mail: chaoguitang@163.com

Genet. Mol. Res. 14 (1): 1828-1835 (2015)

Received April 28, 2014

Accepted August 27, 2014

Published March 13, 2015

DOI http://dx.doi.org/10.4238/2015.March.13.11

\begin{abstract}
The aim of this study was to investigate the mechanism underlying the drug resistance of Acinetobacter baumannii toward aminoglycosides. A total of $32 \mathrm{~A}$. baumannii strains were identified by molecular identification and subsequently isolated. The isolates were then amplified by polymerase chain reaction to analyze the 9 aminoglycoside-modifying enzyme genes and 7 16S rRNA methylase genes. Five types of aminoglycoside-modifying enzyme genes and 1 type of $16 \mathrm{~S}$ rRNA methylase gene were detected in the 32 drug-resistant $A$. baumannii strains. Positive genes included 7 detection modes, of which the all-6-gene-positive mode aac (2')$I b+a a c(3)-I+a a c\left(6^{\prime}\right)-I b+a n t\left(3^{\prime \prime}\right)-I+a p h\left(3^{\prime}\right)-I+\operatorname{armA}$ exhibited the largest number of strains $(12,37.5 \%)$. The resistance of $A$. baumannii against aminoglycosides resulted from the presence of 5 types of aminoglycoside-modifying enzyme genes and the 16S rRNA methylase gene $\operatorname{armA}$. This study is the first to isolate the $\operatorname{arc}\left(2^{\prime}\right)-$
\end{abstract}


$I b$ aminoglycoside-modifying enzyme gene from $A$. baumannii in a domestic clinical setting.

Key words: $16 \mathrm{~S}$ rRNA methylase gene; Acinetobacter baumannii; Aminoglycosides; Aminoglycoside-modifying enzyme gene; Molecular identification; Resistance

\section{INTRODUCTION}

According to the 2nd annual report of Ministry of Health National Antimicrobial Resistance Investigation Net, Acinetobacter baumannii is the most commonly isolated pathogenic bacteria in the intensive care unit (Xiao, 2010; Xiao et al., 2012). The monitoring report of another collaboration group (Wang et al., 2011) showed that the resistance rate of clinically isolated A. baumannii was 2-fold higher than clinically isolated Pseudomonas aeruginosa (Wang et al., 2011). The resistance of clinically isolated A. baumannii is continuously increasing and has triggered widespread concern in global medical communities (Perez et al., 2007; Munoz-Price and Weinstein, 2008; Peleg et al., 2008; Potron et al., 2009).

Bacteria can acquire drug resistance-related genes from movable genetic elements such as plasmids, integrons, and transposon and insertion sequences. Moreover, their own genes and the genes they carry (including resistance genes) can be transferred within the same bacterial species or to different bacterial strains; these phenomena led to rapid distribution of the resistance gene (Bennett, 2008; Potron et al., 2009). More than a decade has passed since the appearance of the multidrug-resistant $A$. baumannii in the mid-1990s, to the pan-drugresistant $A$. baumannii, until the first appearance of the extreme drug-resistant $A$. baumannii (Wang et al., 2012b). Clinical experience and in vitro studies have both suggested that a combination of aminoglycosides and $\beta$-lactam drugs remains the most effective drug therapy for infective diseases caused by A. baumannii (Huang and Liu, 2013). However, resistance to $\beta$-lactams increases with increased resistance of the clinically isolated $A$. baumannii against aminoglycosides. National monitoring has shown that the resistance of clinically isolated strains of A. baumannii against aminoglycosides has remained high for 2 consecutive years (Xiao et al., 2012).

The resistance mechanism of $A$. baumannii against aminoglycosides is thought to mainly involve the acquisition of the aac, ant, and aph genes, which encode $N$ acetyltransferase, $O$-nucleoside transferase, and $O$-phosphate transferase, respectively, through mobile genetic elements. These enzymes can modify specific aminoglycoside groups that enter bacterial cells; this modification results in a loss of aminoglycoside biological activities (Mingeot-Leclercq et al., 1999). In addition, the mechanism is related to the 16S rRNA methylase (Mingeot-Leclercq et al., 1999; Yu et al., 2010) and drug "efflux pumps" (Sun et al., 2010; Luo et al., 2011), which have been widely examined in recent years.

Chinese researchers have also studied the resistance mechanisms of $A$. baumannii against aminoglycosides (Potron et al., 2009; Wang et al., 2012a). In China, the problems associated with the $16 \mathrm{~S}$ rRNA methylase gene $\operatorname{arm} A$-mediated multiple resistance against aminoglycoside antibiotics have become serious. The presence of A. baumannii strains in 25 
hospitals in 6 domestic provinces and cities was observed, with the armA gene reported in 23 hospitals; moreover, the positive rate of the armA gene increased to $47.7 \%$, which is considerably higher than that in other countries and regions (Adams et al., 2009). Recently, Doi et al. (2007) detected aac(2')-Ib aminoglycoside-modifying enzymes, which can modify gentamicin and tobramycin, among others, in A. baumannii.

The antimicrobial drug resistance of clinically isolated $A$. baumannii strains in our hospital has become serious with the detection of multidrug-resistant and pan-drug resistance A. baumannii strains. To investigate the mechanism underlying the resistance of these microorganisms to aminoglycosides, the presence of 9 types of aminoglycoside-modifying enzyme genes and 7 types of 16S rRNA methylase genes was determined in 32 clinically isolated specimens of $A$. baumannii.

\section{MATERIAL AND METHODS}

\section{Strain source, strain molecular identification, and drug susceptibility test}

The 32 strains were isolated from hospitalized patients in Huai'an First Hospital, Jiangsu Province, China, from January 2013 to March 2013. The samples collected included 28 specimens of sputum, 1 specimen of blood, 1 of pus, 1 of oozing fluid, and 1 of cerebrospinal fluid. All strains were identified as $A$. baumannii using a Medical Bacterial Identification Instrument (Zhuhai Deere Biological Engineering Co., Ltd., Shen Zhen, China) and an integrated 96-E bacterial identification card. The 32 strains were subjected to $16 \mathrm{~S}-23 \mathrm{~S}$ rDNA $A$. baumannii-specific polymerase chain reaction (PCR) amplification to identify the molecular species. The results confirmed that all strains were $A$. baumannii. The primer sequences used for the 16S-23S rDNA A. baumannii-specific PCR amplification were P1: 5'-CATTATCA CGGTAATTAGTG-3' and P2: 5'-AGAGCACTGTGCACTTAAG-3' (Chen et al., 2007). A genetic testing kit was provided by the Wuxi Institute of Cloning Genetic Technologies (Wuxi, China). The drug susceptibility test kit was used with a Zhuhai Deere Medical bacterial identification instrument and the integrated 96-E bacterial identification card. Standard susceptibility of the antimicrobial drug was determined according to the US Clinical and Laboratory Standards Institute (2011).

\section{Bacterial treatment}

Single colonies were selected and placed in $0.5-\mathrm{mL}$ Eppendorf centrifuge tubes (Hamburg, Germany) containing $400 \mu \mathrm{L}$ freshly prepared $200 \mu \mathrm{g} / \mathrm{L}$ proteinase K solution. The tubes were heated in a water bath at $56^{\circ} \mathrm{C}$ for $2 \mathrm{~h}$. Next, the water bath temperature was increased to $95^{\circ} \mathrm{C}$ for $10 \mathrm{~min}$. The supernatant was used as the genetic testing template and stored at $-20^{\circ} \mathrm{C}$ until use.

\section{Genetic testing}

Nine types of aminoglycoside-modifying enzyme genes [aac(2')-Ib, aac(3)-I, aac(3)$I I, a a c\left(6^{\prime}\right)-I a d, a a c\left(6^{\prime}\right)-I b, a a c\left(6^{\prime}\right)-I I$, ant ( $\left.3^{\prime \prime}\right)-I$, ant (2")-I, and $\left.a p h 3^{\prime}-I\right]$ and 7 types of $16 \mathrm{~S}$ rRNA methylase genes ( $\operatorname{arm} A, r m t A, r m t B, r m t C, r m t D, r m t E$, and $n p m A)$ were detected using the 
PCR assay. The primer sequences for $a a c$ (2')-Ib were P1: 5'-ATGCAGTTCAAAATTATCGC AGCC-3' and P2: 5'-CTACCAAAGTTCACCTTCTCGCC-3' (product length: 543 base pairs); and the primer sequences for $r m t E$ were P1: 5'-ATGAATATTGATGAAATGGTTG-3' and P2: 5'-TCATTGATTTCCTCCGTTTTTGG-3' (product length: 822 base pairs). The use of these primer sequences was authorized by Zuhuang Mi, Wuxi Institute of Cloning Genetic Technologies. These sequences were used to complete the design according to the conserved regions of the $a a c\left(2^{\prime}\right)-I b$ and $r m t E$ sequences that were downloaded from www.ncbi.nlm. nih.gov/nucleotide before January 1, 2013. The other primer sequences for the aminoglycoside-modifying enzyme genes and 16S rRNA methylase genes for PCR detection are listed in previous reports (Huang et al., 2008; Qu et al., 2008). The PCR amplification system for the various targeted genes (per 20- $\mu \mathrm{L}$ reaction system) consisted of the following: $1 \mu \mathrm{L}$ P1 primer $(1.0 \mu \mathrm{M}), 1 \mu \mathrm{L}$ P2 primer $(1.0 \mu \mathrm{M}), 2 \mu \mathrm{L}$ dNTPs $(2 \mathrm{mM}), 2 \mu \mathrm{L} 10 \mathrm{X}$ buffer $[10 \mathrm{mM}$ $\mathrm{KCl}, 8 \mathrm{mM}(\mathrm{NH} 4)_{2} \mathrm{SO}_{4}, 2 \mathrm{mM} \mathrm{MgCl}, 10 \mathrm{mM}$ Tris- $\mathrm{HCl}, \mathrm{pH} 9.0,0.5 \% \mathrm{NP}_{40}$, and $0.02 \%$ bovine serum albumin (wt/vol)], $1 \mathrm{U}$ Taq DNA polymerase (excluding the volume), $9 \mu \mathrm{L}$ ultrapure water, and $5 \mu \mathrm{L}$ template solution. The thermal cycling parameters for PCR amplification were as follows: denaturation at $93^{\circ} \mathrm{C}$ for $2 \mathrm{~min}$, followed by $93^{\circ} \mathrm{C}$ for $60 \mathrm{~s} \rightarrow 55^{\circ} \mathrm{C}$ for $60 \mathrm{~s} \rightarrow 72^{\circ} \mathrm{C}$ for $60 \mathrm{~s}$, for 35 cycles, and finally a $72^{\circ} \mathrm{C}$ cycle extension of $5 \mathrm{~min}$. The PCR products were analyzed by $2 \%$ agarose gel electrophoresis. The appearance of targeted bands equal in size to the molecular weight of the positive control was considered positive. The genetic testing kit and the positive-control DNA were provided by the Wuxi Institute of Cloning Genetic Technologies.

\section{DNA sequencing}

The full-length forward and reverse sequences of the $a a c\left(2^{\prime}\right)-I b$ aminoglycoside modifying-enzyme gene were sent to Shanghai Boshang Biotechnology Co., Ltd. (Shanghai, China) and subjected to PCR direct automatic fluorescent sequencing.

\section{Sequence comparison}

The Chromas software (Tehnelysium, South Brisbane, Australia) was used for sequence analysis. Chromas sequencing results were then directly compared to those of BLAST.

\section{RESULTS}

\section{Drug susceptibility test}

The drug susceptibility test results for the 32 A. baumannii strains are shown in Table 1. The resistance rates of the 32 strains to 14 commonly used antimicrobial drugs, including gentamicin and amikacin, all exceeded 90\%; high resistance was also observed against imipenem and meropenem. These strains exhibited higher sensitivity only to polymyxin B at a resistance rate of $3.13 \%$. 
Table 1. Drug susceptibility test results of 32 strains of Acinetobacter baumannii (\%)

\begin{tabular}{lccc}
\hline Drug & Resistance $(\mathrm{R})$ & Middle (I) & Susceptable (S) \\
\hline Ampicillin /Sulbactam & $29(90.63)$ & $0(0.00)$ & $3(9.38)$ \\
Piperacillin & $30(93.75)$ & $0(0.00)$ & $2(6.25)$ \\
Piperacillin /Tazobactam & $29(90.63)$ & $0(0.00)$ & $3(9.38)$ \\
Ceftriaxone & $29(90.63)$ & $0(0.00)$ & $3(9.38)$ \\
Cefotaxime & $30(93.75)$ & $0(0.00)$ & $2(6.25)$ \\
Ceftazidime & $29(90.63)$ & $1(3.13)$ & $2(6.25)$ \\
Cefepime & $29(90.63)$ & $0(0.00)$ & $3(9.38)$ \\
Imipenem & $29(90.63)$ & $1(3.13)$ & $6(18.75)$ \\
Meropenem & $29(90.63)$ & $3(9.38)$ & $3(9.38)$ \\
Amikacin & $29(90.63)$ & $0(0.00)$ & $3(9.38)$ \\
Gentamycin & $29(90.63)$ & $0(0.00)$ & $3(9.38)$ \\
Polymyxin B & $1(3.13)$ & $0(0.00)$ & $31(96.88)$ \\
Ciprofloxacin & $29(90.63)$ & $0(0.00)$ & $3(9.38)$ \\
Levofloxacin & $29(90.63)$ & $0(0.00)$ & $3(9.38)$ \\
Tetracycline & $29(90.63)$ & $0(0.00)$ & $3(9.38)$ \\
\hline
\end{tabular}

\section{Genetic testing}

The sequence of the aac(2')-I gene PCR product is shown in Figure 1. The $32 \mathrm{~A}$. baumannii strains all contained $a a c\left(2^{\prime}\right)-I b$ aminoglycoside-modifying enzyme genes and other aminoglycoside-modifying enzyme genes, including $a a c(3)-I, a a c\left(6^{\prime}\right)-I \quad b$, ant( (3")-I, and $\operatorname{aph}\left(3^{\prime}\right)-I$ as well as the $16 \mathrm{~S}$ rRNA methylase gene $\operatorname{arm} A$. The detection rates of the different aminoglycoside-modifying enzyme genes and 16S rRNA methylase gene are shown in Table 2. A total of 5 aminoglycoside-modifying enzyme genes, including $a a c\left(2^{\prime}\right)-I b$, aac(3)-I, $a a c\left(6^{\prime}\right)-I b$, ant (3")-I, and $\operatorname{aph}\left(3^{\prime}\right)-I$, and $116 \mathrm{~S}$ rRNA methylase gene (armA) were found in the 32 A. baumannii strains. The $a a c\left(2^{\prime}\right)-I b$ gene was found in all 32 strains and thus had a positive detection rate of $100 \%(32 / 32)$. The positive rate of the $16 \mathrm{~S}$ rRNA methylase gene arm $A$ was $78.1 \%(25 / 32)$, whereas those of ant(3")-I and $a a c(6)-I b$ were $62.5 \%(20 / 32)$ and $59.4 \%$ (19/32), respectively.

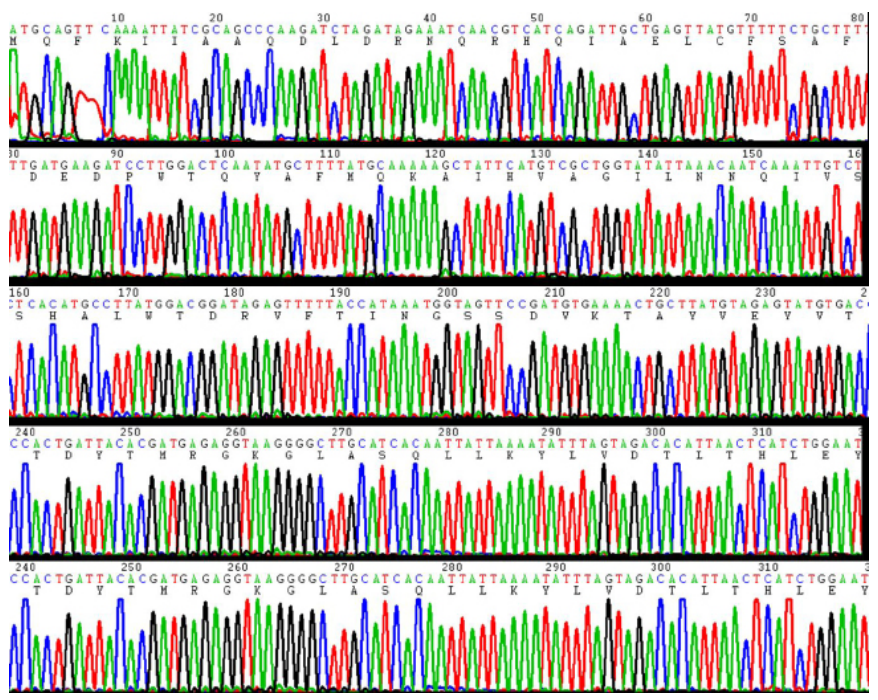

Figure 1. Sequencing of $a a c\left(2^{\prime}\right)-I b$ PCR product. 
Table 2. Detection rates of aminoglycoside-modifying enzyme genes and 16SrRNA methylase genes in 32 strains of Acinetobacter baumannii

\begin{tabular}{lc}
\hline Gene name & Positive ratio (\%) \\
\hline aac( (2')-Ib & $32(100.0)$ \\
$\operatorname{aac}(3)-I$ & $15(46.9)$ \\
$\operatorname{aac}\left(6^{\prime}\right)-I b$ & $19(59.4)$ \\
$\operatorname{ant}\left(3^{\prime}\right)-I$ & $20(62.5)$ \\
$\operatorname{aph}\left(3^{\prime}\right)-I$ & $19(59.4)$ \\
$\operatorname{armA}$ & $25(78.1)$ \\
\hline
\end{tabular}

The detection modes of the aminoglycoside-modifying enzyme genes and 16S rRNA methylase gene are shown in Table 3. The aminoglycoside-modifying enzyme genes were found in all $32 \mathrm{~A}$. baumannii strains. Only 4 strains showed a single detection of the aac (2')-Ib gene $(12.3 \%, 4 / 32)$; the remaining strains contained more than 2 types of genes. The highest detection mode was observed for $a a c\left(2^{\prime}\right)-I b+a a c(3)-I+a a c\left(6^{\prime}\right)-I b+a n t\left(3^{\prime \prime}\right)-I+a p h\left(3^{\prime}\right)-I+a r m A$, which had a positive rate of $37.5 \%(12 / 32)$.

Table 3. Detection modes of positive aminoglycoside-modifying enzyme genes and 16SrRNA methylase genes in 32 strains of Acinetobacter baumannii

\begin{tabular}{lc}
\hline Gene detection mode & Strains (\%) \\
\hline aac(2')-Ib+aac(3)-I+aac(6')-Ib+ant(3")-I+aph(3')-I+armA & $12(37.5)$ \\
$\operatorname{aac}\left(2^{\prime}\right)-\mathrm{Ib}+\mathrm{aac}\left(6^{\prime}\right)-\mathrm{Ib}+\operatorname{ant}\left(3^{\prime \prime}\right)-\mathrm{I}+\mathrm{aph}\left(3^{\prime}\right)-\mathrm{I}+\operatorname{armA}$ & $4(12.3)$ \\
$\mathrm{a}\left(2^{\prime}\right)-\mathrm{Ib}+\mathrm{aac}(3)-\mathrm{I}+\operatorname{ant}\left(3^{\prime \prime}\right)-\mathrm{I}+\operatorname{armA}$ & $1(3.1)$ \\
$\operatorname{aac}\left(2^{\prime}\right)-\mathrm{Ib}+\operatorname{armA}$ & $8(25.0)$ \\
$\operatorname{aac}\left(2^{\prime}\right)-\mathrm{Ib}+\mathrm{aac}(3)-\mathrm{I}+\mathrm{aac}\left(6^{\prime}\right)-\mathrm{Ib}+\operatorname{ant}\left(3^{\prime \prime}\right)-\mathrm{I}+\mathrm{aph}\left(3^{\prime}\right)-\mathrm{I}$ & $2(6.3)$ \\
$\operatorname{aac}\left(2^{\prime}\right)-\mathrm{Ib}+\mathrm{aac}\left(6^{\prime}\right)-\mathrm{Ib}+\operatorname{ant}\left(3^{\prime \prime}\right)-\mathrm{I}+\operatorname{aph}\left(3^{\prime}\right)-\mathrm{I}$ & $1(3.1)$ \\
$\operatorname{aac}\left(2^{\prime}\right)-\mathrm{Ib}$ & $4(12.3)$ \\
\hline
\end{tabular}

\section{DISCUSSION}

Acinetobacter baumannii is a major pathogenic bacteria responsible for nosocomial infection in our hospital. The number of $A$. baumannii strains resistant to quinolones, including imipenem and aminoglycosides, is increasing. Thus, the mechanism by which A. baumannii acquires aminoglycoside-resistant genes should be thoroughly examined.

Aminoglycosides inhibit bacterial protein synthesis. The small $30 \mathrm{~S}$ ribosomal subunit is the platform for the translation and synthesis of bacterial protein. This subunit is the target of aminoglycosides and contains 3 binding sites, including the aminoacyl site, peptidyl site, and exit site. Aminoglycosides can bind to the A site to impede bacterial protein synthesis, resulting in bacterial death (Mingeot-Leclercq et al., 1999).

Currently, the known resistance mechanism of Gram-negative bacillus to aminoglycosides involves the acquisition of $a a c$, ant, and aph genes through mobile genetic elements. These genes encode $N$-acetyltransferase, $O$-nucleoside transferase, and $O$-phosphate transferase, respectively. These aminoglycoside-modifying enzymes can modify specific groups of aminoglycosides that enter bacterial cells; these modifications result in the loss of aminoglycoside biological activities (Fan et al., 2006).

Several foreign studies have been conducted to examine the resistance mechanism underlying multidrug resistance of $A$. baumannii to aminoglycosides (Adams et al., 2009; Wang et al., 2012b). The aminoglycoside-modifying enzymes mediated by plasmids main- 
ly include aac(3)-I (aacCl), aac(3)-II(aac2), aaC(3)III-(aac3), aac(6')-I(aacA4), and aph(3') (aphAl). Adams et al. (2009) found that in the complete genomic sequence of the A. baumannii AB307-0294 strain (NCBI No.: CP001172, 2011-11-21), the median locus tag ABBFA-003344 (sequence, 3557653-3558195; 543 bp) encoded the aac(2')-Ib aminoglycosidemodifying enzyme. We detected the genes of 9 aminoglycoside-modifying enzymes in 32 clinically isolated strains of $A$. baumannii. Table 2 shows that 5 genes, including aac( $\left.2^{\prime}\right)-I b$, $a a c(3)-I, a a c\left(6^{\prime}\right)-I b$, ant( $\left.3^{\prime \prime}\right)-I$, and $a p h\left(3^{\prime}\right)-I$, were found in the 32 strains. Of these, aac(2')-Ib was highly prevalent, with a positive rate of $100 \%(32 / 32)$. This study is the first to isolate aac (2')-Ib aminoglycoside-modifying enzyme genes in China. These genes have been isolated from Mycobacterium tuberculosis abroad and from A. baumannii. The aac(2')-Ib aminoglycoside-modifying enzyme can modify gentamicin and tobramycin (Perez et al., 2007). The positive rates of ant(3")-I and aac(6')-Ib were $62.5 \%(20 / 32)$ and $59.4 \%(19 / 32)$, respectively. These results are similar to those of Huang et al. (2008), but differ from the results of Shi et al. (2005) and Vila et al. (1999).

In recent years, Gram-negative bacilli have been found to obtain various types of $16 \mathrm{~S}$ rRNA methylase genes and express methylases that act upon the targets of aminoglycosides. As a result, aminoglycosides cannot bind to the target sites, resulting in resistance (Fan et al., 2006). The genes coding $16 \mathrm{~S}$ rRNA methylases include $r m t A, r m t B, r m t C, r m t D$, rmtE, npmA, and $\operatorname{arm} A$. In 2010, Davis et al. (2010) reported on the $r m t E$ gene. In the current study, 7 types of $16 \mathrm{~S}$ rRNA methylase genes were detected in 32 clinically isolated multidrug-resistant $A$. baumannii. Table 2 shows that only 1 gene ( $\operatorname{arm} A)$ was found in the 32 strains. The $\operatorname{arm} A$ gene had a positive rate of $78.1 \%(25 / 32)$, which was higher than the $47.7-68.6 \%$ detected in many domestic hospitals. This value was also higher than those reported by Adams et al. (2009), but lower than the $84.5 \%$ reported by Liu et al. (2012). The other 6 types of $16 \mathrm{~S}$ rRNA methylase and the $r m t E$ gene detected in this study were not detected in previous studies. This finding indicates that $\operatorname{arm} A$ is the dominant gene for $16 \mathrm{~S}$ rRNA methylase. Table 3 shows that only 4 strains showed single detection of the $a a c\left(2^{\prime}\right)-I b$ gene $(12.3 \%, 4 / 32)$; the remaining strains were found to contain more than 2 types of genes. The highest detection mode was observed for $a a c\left(2^{\prime}\right)-I b+a a c(3)-I+a a c\left(6^{\prime}\right)-I b+a n t\left(3^{\prime \prime}\right)-I+a p h\left(3^{\prime}\right)-I+a r m A$, which showed a positive rate of $37.5 \%(12 / 32)$.

In this study, the high detection rates of various aminoglycoside-modifying enzyme genes in A. baumannii and the presence of the $16 \mathrm{~S}$ rRNA methylase gene armA were consistent with previously reported results and with the high resistance of $A$. baumannii to aminoglycosides. The high detection rates of aminoglycoside-resistance genes, particularly the linkage communication of the $16 \mathrm{~S}$ rRNA methylase gene and $\beta$-lactamase gene, may lead to the evolution of super-bacteria for which no treatment is currently available. This possibility deserves urgent clinical attention. An epidemiological investigation of the existence of the aac(2')-Ib gene in clinically isolated strains of A. baumannii must be conducted.

\section{REFERENCES}

Adams MD, Nickel GC, Bajaksouzian S, Lavender H, et al. (2009). Resistance to colistin in Acinetobacter baumaunii associated with mutations in the PmrAB two-component system. Antimicrob. Agents Chemother. 53: 3628-3634.

Bennett PM (2008). Plasmid encoded antibiotic resistance: acquisition and transfer of antibiotic resistance genes in bacteria. Br. J. Pharmacol. 153: S347-357.

Bernabeu-Wittel M, Pichardo C, García-Curiel A, Pachón-Ibáñez ME, et al. (2005). Pharmacokinetic/pharmacodynamic 
assessment of the in-vivo efficacy of imipenem alone or in combination with amikacin for the treatment of experimental multiresistant Acinetobacter baumannii pneumonia. Clin. icrobiol. Infect. 11:319-325.

Chen TL, Siu LK, Wu RC, Shaio MF, et al. (2007). Comparison of one-tube multiplex PCR, automated ribotyping and intergenic spacer (ITS) sequencing for rapid identification of Acinetobacter baumannii. Clin. Microbiol. Infect. 13: 801-806.

Davis MA, Baker KN, Orfe LH, Shah DH, et al. (2010). Discovery of a Gene Conferring Multiple-Aminoglycoside Resistance in Escherichia coli. Antimicrob. Agents Chemother. 54: 2666-2669.

Długosz M and Trylska J (2009). Aminoglycoside association pathways with the 30 S ribosomal subunit. J. Phys. Chem. B. 113:7322-7330.

Doi Y, Adams JM, Yamane K and Paterson DL (2007). Identification of 16S rRNA methylase-producing Acinetobacter baumannii clinical strains in North America. Antimicrob. Agents Chemother. 51: 4209-4210.

Fan MQ, Zhao M and Fan J (2006). Recent advances on the structure of $30 \mathrm{~s}$ ribosomal subunit and interaction of $30 \mathrm{~s}$ ribrosome with aminoglycosides. Chin. J. New Drugs 15: 676-682.

Huang ZM, Shan H, Mi ZH, Yang HY, et al. (2008). Analysis on 168 rRNA methylase genes and aminoglycoside modifying enzymes genes in Enterobacter cloacae in China. Zhonghua Liu Xing Bing Xue Za Zhi 29: 369-373.

Huang JX and Liu ML (2013). Pharmacokinetic and pharmacodynamic principles in multidrug resistance of acinetobacter infection treatment application. World Notes Antibiotics 34: 71-76.

Liu XQ, Chen J, Li H, Wang LW, et al. (2012). Study of aminoglycoside drug-resistant gene on the plasmid of Acinotobacter baumannii. Chin. J. Antibiotics 37: 335-337.

Luo L, Jiang X, Wu Q, Wei L, et al. (2011). Efflux pump over-expressionin conjunction with alternation of outer membraneprotein may induce Acinetobacter baumannii resistant to imipenem. Chemotherapy 57: 77-84.

Mingeot-Leclercq MP, Glupczynski Y and Tulkens PM (1999). Aminoglycosides: activity and resistance. Antimicrob. Agents Chemother. 43: 727-737.

Munoz-Price LS and Weinstein RA (2008). Acinetobacter infection. N. Engl. J. Med. 358: 1271-1281.

Peleg AY, Seifert H and Paterson DL (2008). Acinetobacter baumannii: emergence of a successful pathogen. Clin. Microbiol. Rev. 21: 538-582.

Perez F, Hujer AM, Hujer KM, Decker BK, et al. (2007). Global Challenge of Multidrug-Resistant Acinetobacter baumannii. Antimicrob. Agents Chemother. 51: 3471-3484.

Potron A, Poirel L, Croizé J, Chanteperdrix V, et al. (2009). Genetic and biochemical characterization of the first extendedspectrum CARB-type beta-lactamase, RTG-4, from Acinetobacter baumannii. Antimicrob. Agents Chemother. 53: 3010-3016.

Qu W, Mo F, Huang ZZ, Zhang S, et al. (2008). Analysis on 16S rRNA methylase genes and aminoglycoside modifing enzymes genes in Acinetobacter baumannii in China. Zhonghua Liu Xing Bing Xue Za Zhi 28: 727-728.

Shen P, Wei ZQ, Chen YB, Xiao YH, et al (2012). Mohnarin report of 2010: monitoring of bacterial resistance in intensive care units. Chin. J. Nosocomiol. 22: 481-485.

Shi WF, Jiang JP and Mi ZH (2005). Relationship between antimicrobial resistance and aminoglycoside-modifying enzyme gene expressions in Acinetobacter baumannii. Clin. Med. J. 118: 141-145.

Sun JR, Chan MC, Chang TY, Wang WY, et al. (2010). Overexpression of the aseB gene in clinical isolates of tigecylinesusceptible Acinetobacter baumannii without insertion mutations in adeRS. Antimicrob. Agents Chemother. 54: 4934-4938.

Vila J, Ruiz J, Navia M, Becerril B, et al. (1999). Spread of amikacin resistance in Acinetobacter baumannii strains isolated in Spain due to an epidemic strain. J. Clin. Microbiol. 37: 758-761.

Wang H, Zhao CJ, Wang ZW, Ni YX, et al. (2011). Report from Chinese Meropenem Susceptibility Surveillance in 2010: antimicrobial resistance amongnosocomial Gram-negative bacilli. Chin. J. Lab. Med. 34: 897-904.

Wang CX, Geng XL, Xu YF, Chen GQ, et al. (2012a). Correlation between acquired drug resistance-related genes and mobile genetic elements in pandrugresistant Acinetobacter baumannii. Chinese J. Infectious Diseases 32: 115-118.

Wang WH, Chen J, Mao XY, Lv WF, et al. (2012b). Correlation between acquired drug resistance-related genes and mobile genetic elements in pandrugresistant Acinetobacter baumannii. Chin. J. Clin. Infect. Dis. 5: 9-14.

Xiao YH (2010). Mohnarin Annual Report of 2008: Monitoring of Bacterial Drug Resistance in Intensive Care Unit. Chin. J. Nosocomiol. 20: 2384-2388.

Xiao YH, Shen P, Wei ZQ, Chen YB, et al. (2012). Mohnarin report of 2011: monitoring of bacterial resistance in China. Chin. J. Nosocomiol. 22: 4946-4652.

Yu FY, Yao D, Pan JY, Chen C, et al. (2010). High prevalence of plasmid-mediated 16S rRNA methlase gene rmtB among Escherichia coli clinical isolates from a Chinese teaching hospital. BMC Infect. Dis. 10: 184. 